\title{
Seroepidemiological survey of rotavirus in Thailand, 1978
}

\author{
Niwat Maneekarn*, Tatsuhiko Shinozaki**, Kazuko

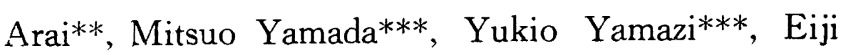 \\ Watari***, and Hiroshi Suzuki*** \\ ${ }^{*}$ Department of Microbiology, Faculty of Medicine, Chiang Mai University \\ **Department of Pediatrics, Teikyo University School of Medicine \\ *** Department of Microbiology and Immunology, Nippon Medical School
}

In 1973, Bishop et al. found rotavirus for the first time with electron microscopy in a biopsy material and a fecal specimen from a child suffering from acute gastroenteritis ${ }^{1)}$. The virus has been confirmed to be a pathogenic agent of an infantile diarrhea in the Tem. perate Zone in winter ${ }^{2 \sim 6)}$.

One hundred and seventy-eight serum samples collected in Thailand in August, 1978 were tested for the complement fixing (CF) antibody to Nebraska calf diarrhea virus (NC DV), which has common antigen(s) with human rotavirus (HRV) and grown in a tissue

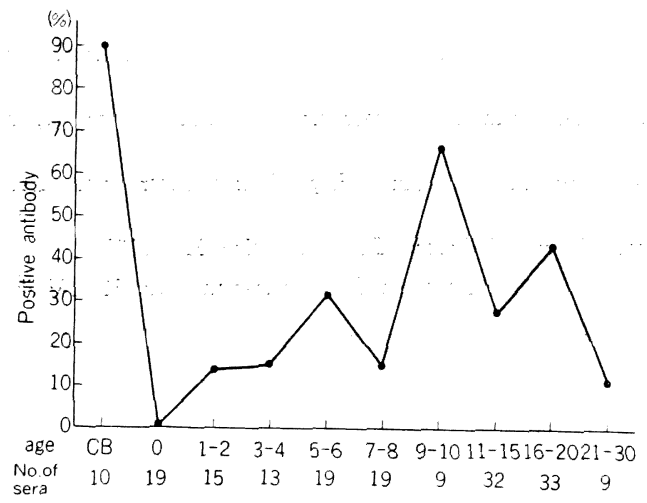

Fig. 1 Distribution of antibody to rotavirus, Thailand, 1978. CB : cord blood culture $^{7)}$. Twenty sera were obtained at Chiang Mai and 158 were at Bangkok and Central Thailand.

The Fig. 1 shows the age distribution of the CF antibody to NCDV, in which $1: 5$ or more of the antibody titers was referred as positive. The percentage of the positive cases in 9 10 years of age is greater than $0 \sim 4,7 \sim 8,11 \sim 15$, and $21 \sim 30$ years of age, respectively (chi square test, $p<0.05)$. The antibody to rotavirus appeared since $1 \sim 4$ years after birth, then increased to the maximum at 9 10 years of age, and decreased thereafter. The presence of $90 \%$ positive antibody cases in cord blood reflects the maternal antibody and 0 for 0 year of age may be its disappearance. Although it is not completely clear why many samples of cord sera contained the RT-CF antibody, it should be mentioned that cord blood samples were collected in Bangkok.

According to Urasawa et al. ${ }^{6}$, who studied the age distribution of NCDV-antibody at Sapporo, about $90 \%$ of 3 to 5 years old children had the antibody. It is apparent that the rotavirus infection occured frequently at older age $s$ in Thailand than in Japan. How. 
ever, the virus-neutralizing (VNT) antibody to HRV determined with the fluorescent focus

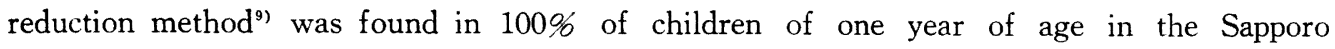
sera $^{6}$. If antibody of serum samples from Thailand were tested with the fluorescent focus reduction method to $\mathrm{HRV}$, acquisition of the antibody could be found more frequently in young age groups than those in our results of this paper.

Diarrhea with HRV has been reported also in the Tropical Zone ${ }^{10 \sim 12)}$, and diarrhea is one of the most important diseases in Thailand. The precise survey of HRV and diarrhea among Thei children should be conducted in the future.

\section{REFERENCES}

1) Bishop, R.F., Davidson, G.P., Holmes, I.H., and Ruck, B.J. : Lancet, ii, 1281 1283, 1973 : Bishop, R.F., Davidson, G.P., Holmes, I.H., and Ruck, B.J. : Lancet, i, 149 151, 1974.

2) Konno, T. : J. Infect. Dis., 135, 259 266, 1977.

3) Kogasaka, R., and Nakao, T. : Shonika, 18, 967 976, 1977. (in Japanese)

4) Shinozaki, T., Fujii, R., Sato, K., Takahashi, E., Ito, Y., and Inaba, Y. : Lancet, i, 877 878, 1978.

5) Suzuki, S. : Saishin Igaku, 33, 1588 1607, 1978. (in Japanese)

6) Urasawa, S., and Akiba, S. : Clinical Virol., 7, 339 349, 1979. (in Japanese)

7) Kapikian, A.Z., Cline, W.L., Mebus, C.A., Wyatt, R.G., Kalica, A.R., James, H.D., Jr., Van Kirk, D., Chanock, R.M., and Kim, H.W. : Lancet i, 1056 1061, 1975.

8) Bryden, A.S., Davis, H.A., Thouless, M.E., and Flewett, T.H. : J. Med. Microbiol., 10, 121 125, 1970.

9) Thouless, M.E., Bryden, A.S., Flewett, T.H., Woode, G.N., Bridger, J.C., Snodgrass, D.R., and Herring. J.A. : Arch. Virol., 53, 287 294, 1977.

10) Ryder, R.W., Sack, D.A., Kapikian, A.Z., Rahman, A.S. M.M., Merson, M.H., and Wells, J.G. : Lancet, i. $659 \sim 662,1976$.

11) Schoub, B.J., Koornhof, H.J., Lecatsas, G., Prozesky, O.W., Freiman, I., Hartman, E., and Kassel, H. : Lancet, i, 1093 1094, 1975.

12) Hieber, J.P., Shelton, S., Nelson, J.D., Leon, J., and Mohs, E. : Am. J. Dis. Child., 132, 853 858, 1978. 